\title{
Efficiency of Student Mini-Company Developing Personal Qualities
}

\section{Džiuljeta Ruškytè}

Lithuanian University of Educational Sciences, Faculty of Social Education, Department of Economics and Entrepreneurship Education, 31 T. Ševčenkos St., LT-03111 Vilnius, Lithuania, dziuljeta.ruskyte@leu.lt

\begin{abstract}
On the basis of scholarly literature analysis, the article discusses the structural components of personal qualities that are developed most participating in activities of student mini-company (hereinafter - SMC). Applying the exploratory factor analysis (EFA), the evaluation of personal qualities of school learners, who participated in SMC activities, was conducted and the efficiency of SMC was substantiated separately evaluating structural components of personal qualities divided into relevant structural groups: Qualities of self-confidence, motivation and activity, Leadership qualities, Managerial qualities and Personal self-expression qualities. The results showed that participation in the activities of SMC has a considerable influence on development of school learners' personal qualities. The EFA results of development of personal qualities through SMC activities disclosed that out of the four distinguished groups of personal qualities the school learners developed the qualities of self-confidence, motivation and activity best. The evaluation of 18 personal qualities revealed that diligence, ambitiousness, initiative, independence, activity and resourcefullness were developed best, whereas critical-analytical thinking was developed least.
\end{abstract}

Keywords: personal qualities, student mini-company, efficiency, entrepreneurship education, exploratory factor analysis.

\section{Introduction}

Relevance. The analysis of conducted research and other sources show that practical entrepreneurship education, which is based on implementation of various programmes and activities of student mini-companies, is one of the most significant factors that promote setting up and development of business (Martínez, Levie, Kelley, Sæmundsson, 
\& Schøtt, 2010, pp. 9-10; Guidance Supporting Europe's Aspiring Entrepreneurs - Policy and Practice to Harness Future Potential, 2011; Building Entrepreneurial Mindsets and Skills in the EU, 2012; Johansen \& Schanke, 2013; Elert, Anderssonb, \& Wennberg, 2015; Komarkova, Conrads, \& Collado, 2015; Komarkova, Gagliardi, Conrads, \& Collado, 2015; Ruskovaara \& Pihkala, 2015; Dèl novatoriško verslumo ugdymo sampratos tvirtinimo, 2016; Lietuvos Junior Achievement (LJA); and others).

The research reports and documents distinguish entrepreneurship as a priority direction in educational activities and it is described as one of the key general competencies. The return of the investment in entrepreneurship education can be among the most considerable ones in European countries because about $15-20 \%$ of school learners, who participated in the activities of SMC, later started their own business (Flash Euro barometer 354, 2012, p. 18, p. 77; Entrepreneurship 2020 Action Plan, 2013, p. 5; Lietuvos verslumo veiksmu 2014-2020 metu planas, 2014). Therefore, schools are encouraged to promote school learners' participation in their activities and it is recommended for educational institutions to provide support to them and to integrate them into curriculum because goals and learning outcomes set out in other study subjects are also achieved implementing SMC activities. To make appropriate decisions and to attain the goal, personal qualities and abilities related to entrepreneurship are as important (Elert, Anderssonb, \& Wennberg, 2015).

Problem. The efficiency of entrepreneurship education programmes has been analysed from different aspects in a big number of works by foreign and Lithuanian scholars (Strazdienė \& Garalis, 2005; Fayolle, Gailly, \& Lassas-Clerc, 2006; Fayoll \& Gailly, 2008; Oosterbeek, Van Praag, \& Ijsselstein, 2008; Draycott \& Rae, 2011; Draycott, Rae, \& Vause, 2011; Donielienè, Každailytė, \& Širiakovienė, 2012; Hamilton, \& Hamilton, 2012; Halabisky, 2012; Johansen, Clausen, \& Schanke, 2013; Johansen \& Schanke, 2013; Ruskovaara \& Pihkala, 2013; Johansen \& Somby, 2015; Komarkova, Gagliardi, Conrads, \& Collado, 2015; Ruskovaara \& Pihkala, 2015; Elert, Anderssonb, \& Wennberg, 2015; and others) but, with exception of several works, where possibilities for development of entrepreneurship competency of upper secondary school learners through SMC activities are analysed on a fragmented basis, in-depth research studies on the issue are not available. The efficiency of SMC activities development of personal qualities has not been analysed from the scientific perspective. Therefore attempts are made to answer the question about the efficiency of SMC developing personal qualities.

The goal: to evaluate efficiency of student mini-company developing personal qualities of an individual.

\section{The objectives:}

1. Following the analysis of the scholarly literature, to discuss the structural components of personal qualities that are best developed in SMC activities.

2. To carry out factor analysis and to evaluate the level of development of the school learners' personal qualities in SMC activities in a quantitative way. 


\section{The research methods and the stages of research organisation}

The analysis of scholarly literature was conducted to discuss structural components of personal qualities that are strongest developed in SMC activities.

The questionnaire survey of school learners was carried out to qualitatively evaluate the level of development of personal qualities of school learners involved in SMC activities and to substantiate efficiency of SMC developing entrepreneurship competency.

The targeted sampling of school learners of general education schools involved in SMC activities was conducted using the method of simple random sample (Čekanavičius \& Murauskas, 2000, p. 10, pp. 13-14). According to the data of LJA in the school year of 2013-2014 there were 161 SMCs, which united 1324 school learners. They made up the general population of the research.

Considering $95 \%$ of reliability and $5 \%$ of random error, which, according to V. Čekanavičius and G. Murauskas (2000), depends on the size of the sample and applying the spreadsheet of the sample size, the recommended number of the respondents should be at least 298 participants (see: Raosoft). The probability sampling of the research consisted of 303 learners participating in SMC activities.

A questionnaire was devised for learners involved in SMC activities. A 5-point scale was applied in the questionnaire for assessment of personal qualities, which facilitates establishment of the order of increase and decrease in differences of a certain variable (Pranulis \& Dikčius, 2012, p. 217, p. 219).

The analysis of the data of the school learners' questionnaire survey was conducted with the help of the specialised statistical programme IBM ${ }^{\circledR}$ SPSS ${ }^{\circledast}$ Statistics for Windows 22.0 (SPSS).

The exploratory factor analysis (EFA) (Čekanavičius \& Murauskas, 2002; Morkevičius, 2008; Garson, 2013) was used for establishment of correlation of structural components of personal qualities developed in SMC activities and, following the identified correlation, to classify them into the related latent factors according to certain qualities.

The correlation analysis (CA) was employed to establish a statistical link among the variables (structural components of personal qualities).

The principal component analysis (PCA) was used to reduce the numbers of multidimensional data (Dzemyda, Kurasova, \& Žilinskas, 2008, p. 44; Garson, 2013) and to receivenon-correlation variables of orthogonal transformation.

The factor rotation was conducted seeking to obtain factors that can be explained in a more simple and easier way (Vaitkevičius \& Saudargienè, 2006, p. 192). Applying Varimax, an orthogonal factor rotation method, the number of variables that are significantly related to every factor were minimalised (Morkevičius, 2008), the components of personal qualities, which acquired a certain factorial weight (when factorial weights range from 0.700 to 0.900 - good, from 0.500 to 0.700 - average, from 0.300 to 0.500 - weak) were assigned to a relative latent factor. 


\section{Development of personal qualities}

Entrepreneurship is related to establishment of business companies and organisation of business in numerous works and it is interpreted as personal qualities and abilities to create added value, which are characteristic of entrepreneurs (Minciené, 2000; Kickul \& Gundry, 2002; Baum \& Locke, 2004; Mitchelmore \& Rowley, 2010; Elert, Anderssonb \& Wennberg, 2015; and others).

Personal qualities refer to "an aggregate of the individual's qualities that predetermine his/her activities and behaviour, independence and responsibility” (Jovaiša, 2007, p. 22). A personal quality is "a relatively steady peculiarity of the individual's behaviour, which tends to repeat in various situations, $<\ldots>$ a concept, which describes value-based orientation as a unity of cognition, emotional experience and behaviour" (Bitinas, 2011, p. 29).

Developing personal competence, attempts are made to enable students to develop their ability to adequately evaluate and improve own personal qualities, to pursue the set aims in a targeted and adequate way, to follow universally accepted moral norms, to foresee possibilities for choice, to cope with difficulties, etc. (Bendruju kompetenciju ugdymas. Vidurinio ugdymo bendruju programu 10 priedas, 2011, pp. 3-4).

J. R. Baum and E. A. Locke established a close link among knowledge, skills, motivation and personal qualities required for a particular activity and stated that it is their dynamics (acquisition of new knowledge, entrepreneurship skills and development of personal qualities) in the process of activity that predetermines the success of that activity. The following qualities, related to activity perspectives, are assigned to individual personal qualities: initiative, which determined as direction of inner energy and actions towards pursuance of the set goals, a striving for implementation of new possibilities of perspective activities and persistence, when difficulties are encountered; enthusiasm as the main quality of successful leadership that is linked with future perspectives of an enterprise; activity, which is regarded as an intention to act and to take concrete actions (Baum \& Locke, 2004, p. 587, p. 598). This quality is also emphasised by American scholars J. Kickul and L. Gundry (2002). According to them, active individuals have active social relations, are able to foresee long-termeconomic forecasts, which enable them to successfully exploit new possibilities for the growth of their enterprise (Kickul \& Gundry, 2002, p. 87).

Initiative is a quality characteristic of a motivated individual, who is able to function independently and to make independent decisions. People with initiative tend to work much and independently, they complete the most complicated assignments on time and without additional efforts, pursue ambitious goals, are self-confident and believe in their own abilities and search for new opportunities(Baum \& Locke, 2004). To possess initiative means to assume responsibility for the results of own activity (Covey, 2006, p. 82). Initiativeis also understood as the individual's diligence (Peleckis, Peleckiene \& Peleckis, 2013, p. 352). "An active person persuades others, is self-confident, initiates ac- 
tivities, isrelative, able to lead others and to manage the situation. She/he enables himself or herself and others to engage actively" (Gumuliauskienė \& Vaičiūniené, 2015, p. 39).

Persistence is "a consistent long-term pursuance of a goal under complicated or hostile objective or subjective conditions of activities" (Jovaiša, 2007). Persistence allows to achieve good learning outcomes, results of work and to develop abilities.

Many scholars particularly emphasise the importance of motivation organising and developing business. Motivation is determined as an internal driving force, which encourages activities and achievement of the set goals. Motivation is a stimulus to attain a certain goal or result that behaviour is directed to. L. J. Mullins (2005) determines motivation as a driving force seeking to satisfy personal needs and expectations (to get economic benefit, to feel internal satisfaction, to maintain social relations). The person's internal motivation is particularly important making decisions in the process of activities foreseeing perspectives of an enterprise. Motivation is an essential factor developing entrepreneurship. Personal motives foster accumulation of knowledge, development of abilities seeing future perspectives (Heinonen \& Hytti, 2010).

Ambitiousness is a quality of an ambitious person, who possesses a goal. Ambitious people feel their own value and seek recognition. They are motivated, determined, tough and frequently surpass own expectations, when new challenges are faced (Entrepreneurship Competency Model, pp. 4-6).

Self-esteem is understood as a sense of high or low self-worth (Myers, 2008). Thus, learning motivation, demonstration of self-esteem, efforts and interests in the educational process depend on the perception of self-esteem.

Responsibility is linked with a positive attitude of the learners towards business as well as motivated, well-reasoned decisions, with a targeted attainment of goals implementing a specific assignment or activities (Draycott \& Rae, 2011; Ruskovaara, 2014; Rasmussen, Moberg, \& Revsbech, 2015).

Successful collaborative learning boosts perception of school learners' self-esteem, confidence in own abilities, contributes to development of independence (Sahlberg, 2004). Independence is an essential personal quality, which allows to make conscious choices of goals, means and ways of activities and communication, tobe active and efficient in activities (Jovaiša, 2007). According to G. Petty, independence increases school learners' learning motivation, develops abilities and attitudes of independent learning, a sense of responsibility, etc. (Petty, 2008, pp. 417-423).

Self-confidence is a belief in own abilities and advantage in certain spheres or situations. "People, who are self-confident, express belief in their own abilities and in implementation of goals, foster confidence in surrounding people as well. All this results in an easier acquisition of support from the environment while implementing personal goals" (Šilingienè, 2011, p. 966).

A person with well-developed communication skills is able to establish contacts with people from various social layers and to cope with conflict situations. Communicability 
can be associated with abilities of interpersonal communication. This embraces abilities to exchange information and experience, to establish and maintain interpersonal relations (Jovaiša, 2007, p. 36). A communicable person is able and disposable to open communication with other people (Tarptautiniu žodžiu žodynas, 2013, p. 431).

A well-developed personal quality of honesty closely related to attitudes of moral behaviour, evaluation and implementation of own potential and abilities in a specific situation and to performance of assigned or chosen functions in certain activities.

Invarious sources integrity is linked with good repute of an individual, his/her respectable behaviour, not taking advantage of other people's mistakes or ignorance, intolerance of actsof unlawful interference and ability to take appropriate measures to discontinue them.

Creativity and creative thinking are frequently mentioned in scholarly literature sources. Creativity is often determined as a personal quality related to ability to discover and envisage something that is new, original and unexpected (Zabielavičiené, 2013, p. 241). Creative thinking is the highest form of productive thinking, which embraces such dimensions of verbal and non-verbal thinking as abundance of ideas, flexibility of thinking, originality and particularity (Beresnevičius, 2010, p. 27). This embraces possession of vivid imagination and engagement into the activity process (Jovaiša, 2011, p. 304). To think creatively means the ability to change own opinion under certain circumstances and to consistently understand the sequence of ideas and thoughts, to be able to present them in an interesting and persuasive way (Petrulyte, 2007, p. 90).

Far-sightedness is defined as an ability to concentrate on future perspective and foreseeing strategic goals by B. Bird, who conducted research on the factors that precondition entrepreneurship competency and their influence on business (Bird, 1995, p. 51, p. 72). An individual with far-sightedness is able to understand motives of other people, respect their attitude and opinion and is able to combine verbal and non-verbal behaviour.

Resourcefulness is distinguished in the process of education and linked to vivid imagination, creativity, ability to create innovative ideas and to make decisions in the process of education (Dudaitė \& Žibènienè, 2012, p. 166).

Critical-analytical thinking is associated with an ability to understand and analyse the received information and to make specific decisions (Gudžinskienè, 2006; Jovaiša, 2007).

Table 1 was compiled by the author of the article on the basis of the analysed scientific works, the data of international research, methodological recommendations to implementers of SMC and other sources. 


\section{Table 1}

Personal qualities

\begin{tabular}{l|l|l}
\hline Activity & Resourcefulness & Self-confidence \\
\hline Ambitiousness & Far-sightedness & Integrity \\
\hline Persistence & Communicability & Independence \\
\hline Responsibility & Critical-analytical thinking & Self-esteem \\
\hline Enthusiasm & Creativity & Honesty \\
\hline Initiative & Motivation & Diligence \\
\hline
\end{tabular}

The assessment data of all the personal qualities developed by school learners in the process of SMC activities, which were chosen having conducted the EFA, are provided further.

\section{The results of exploratory factor analysis of development of personal qualities implementing activities in student mini- company}

The EFA was applied to establish links among structural elements of personal qualities developed in the activities of SMC and, on the basis those identified links, to classify them according to certain features into the respective latent factors.

To carry out the research on school learners' personal qualities developed conducting activities in SMC, 18 variables - personal qualities were chosen and analysed out of all the data entered in SPSS (see: Table 2).

The correlation matrix showed the correlation of the analysed data because the elements of diagonal elements of correlation are equal to one. The anti-image matrices show the interim result between variables and factors, i.e., negative or positive correlation between a variable and a factor.

The Keiser-Meyer-Olkin measure (KMO) is an index for comparing magnitudes of observed correlation coefficients to magnitudes of partial correlation coefficients. According to V. Čekanavičius and G. Murauskas (2002), KMO, which is equal to 0.808, shows good adequacy of variables for the factor analysis (see: Table 2).

Seeking to identify if statistically significant correlation is observed among measurable variables, the Bartlett's Test of Sphericity was applied.

The following hypotheses were tested:

$\mathrm{H}_{0}$ : all the measured variables are non-correlated;

$\mathrm{H}_{\mathrm{a}}$ : significant correlation is observed among variables. 
Table 2

Reliability statistics and Kaiser-Meyer-Olkin and Bartlett's test

\begin{tabular}{c|c|l|l|l|l|l}
\hline \multicolumn{3}{c|}{ Reliability Statistics } & \multicolumn{3}{|c}{ Kaiser-Meyer-Olkin and Bartlett's Test } \\
\hline N of Items & $\begin{array}{l}\text { Cronbach's } \\
\text { Alpha }\end{array}$ & $\begin{array}{l}\text { Cronbach's } \\
\text { Alpha } \\
\text { Based on } \\
\text { Standar- } \\
\text { dized Items }\end{array}$ & $\begin{array}{l}\text { Kai- } \\
\text { ser-Meyer-Ol- } \\
\text { kin Measure } \\
\text { of Sampling } \\
\text { Adequacy }\end{array}$ & $\begin{array}{l}\text { Bartlett's Test of Sphericity } \\
\text { Approx. } \\
\text { Chi-Square }\end{array}$ & df & Sig. \\
\hline 18 & 0.917 & 0.917 & 0.808 & 3953.325 & 153 & 0.000 \\
\hline
\end{tabular}

The Bartlett's Test of Sphericity allowed to conclude (see: Table 2) that all the variables were significantly interrelated as the level of significance equalled (Sig.) $<0.05$. It is seen that the value of $p$ equaled $0.000<0.05$, therefore, factor analysis can be applied for the possessed data.

The values of the Cronbach's alpha coefficient 0.917 (see: Table 2) revealed a very good internal reliability of the questionnaire scale. The suitability of the variables for EFA was also proved by their measures of sampling adequacy (MSA), which were at least 0.05.

The principal component analysis (PCA) was applied transforming multivariate data (reduction of number of parameters) and distinguishing non-correlation factors.

Applying Varimax, i.e., the orthogonal factorial rotation method, the number of the variables with high factorial weights was reduced and the factor dispersion was maximised. This allowed to link the variables with a respective latent factor.

Only the components with the initial eigenvalues higher than one are important in the EFA. The initial eigenvalues that are bigger than $1(7.660 ; 1.991 ; 1.722 ; 1.396)$ show that four factors are suitable for EFA.

Table 3 shows that the first four factors make up $70.93 \%$ of the total dispersion of all the variables. Before the rotation, the value of factor $\mathrm{F}_{1}$ constituted $42.55 \%$ of the total dispersion and after the rotation sums of squared loadings, this value went down to $22.73 \%$; the proportion of the total dispersion of factor $\mathrm{F}_{2}$ before the rotation equalled $11.06 \%$ and was $17.80 \%$ after it, those of factor $\mathrm{F}_{3}-9.57 \%$ and $17.74 \%$ respectively, and those of $\mathrm{F}_{4}-7.75 \%$ and $12.67 \%$ respectively. The proportion of the total dispersion remained the same $(70.93 \%)$. 
Table 3

The results of exploratory factorial analysis of development of personal qualities through SMC activities

\begin{tabular}{|c|c|c|c|c|}
\hline Factor & $\mathrm{F}_{1}$ & $\mathrm{~F}_{2}$ & $\mathrm{~F}_{3}$ & $\mathrm{~F}_{4}$ \\
\hline Personal qualities & $\begin{array}{l}\text { Qualities } \\
\text { of self-con- } \\
\text { fidence, } \\
\text { motivation } \\
\text { and activity }\end{array}$ & $\begin{array}{c}\text { Leadership } \\
\text { qualities }\end{array}$ & $\begin{array}{c}\text { Managerial } \\
\text { qualities }\end{array}$ & $\begin{array}{c}\text { Personal } \\
\text { self-expres- } \\
\text { sion quali- } \\
\text { ties }\end{array}$ \\
\hline $\begin{array}{l}\text { The proportion of total dispersion } \\
70.93 \%\end{array}$ & $22.73 \%$ & $17.80 \%$ & $17.74 \%$ & $12.67 \%$ \\
\hline Factor components & $\mathbf{L}^{*}$ & $\mathbf{L}$ & $\mathbf{L}$ & $\mathbf{L}$ \\
\hline Diligence & 0.825 & & & \\
\hline Self-esteem & 0.775 & & & \\
\hline Self-confidence & 0.703 & & & \\
\hline Motivation & 0.621 & & & \\
\hline Honesty & 0.617 & & & \\
\hline Communicability & 0.590 & & & \\
\hline Enthusiasm & 0.586 & & & \\
\hline Ambitiousness & & 0.756 & & \\
\hline Persistence & & 0.700 & & \\
\hline Responsibility & & 0.687 & & \\
\hline Integrity & & 0.648 & & \\
\hline Initiative & & & 0.868 & \\
\hline Independence & & & 0.830 & \\
\hline Activity & & & 0.811 & \\
\hline Critical-analytical thinking & & & 0.492 & \\
\hline Resourcefulness & & & & 0.844 \\
\hline Creativity & & & & 0.587 \\
\hline Far-sightedness & & & & 0.529 \\
\hline
\end{tabular}

${ }^{*} \mathrm{~L}-$ factorial weight.

Conducting the transformation of school learners' personal qualities in the rotated component matrix using the Varimax method, four factors (groups of personal qualities) were distinguished, which make up $70.93 \%$ of the total dispersion (of all the evaluated personal qualities): $F_{1}$ embraces group ofqualities of self-confidence, motivation and activity (activity, self-confidence, self-confidence, motivation, honesty, communicability, enthusiasm) and makes up $22.73 \%$ of the total dispersion; $F_{2}$ includes group of leadership qualities (ambitiousness, persistence, responsibility, integrity) with $17.80 \%$ of the dispersion; $F_{3}$ covers group of managerial qualities(initiative, independence, activity, critical-analytical thinking) with $17.74 \%$ of the total dispersion; $\mathrm{F}_{4}$ consists of group of 
personal self-expression qualities (resourcefulness, creativity, far-sightedness) with $12.67 \%$ of the total dispersion.

Table 3 presents the evaluation data of all the personal qualities of school learners developed in SMC activities, which were chosen using the EFA.

The EFA data (factorial weights) of personal qualities of school learners, who take part in SMC activities, show that with exception of several components, the school learners developed them well or sufficiently (when factorial weights range from 0.700 to 0.900 - good, from 0.500 to 0.700 - average, from 0.300 to 0.500 - weak). The heavier the factorial weight, the closer it is to the respective factor.

The factorial weights show that diligence (0.825), self-esteem (0.775) and self-confidence (0.703) are the qualities developed best in the group of qualities of self-confidence, motivation and activity $\left(\mathrm{F}_{1}\right)$; ambitiousness $(0.756)$ and persistence $(0.700)$ - from the group of leadership qualities $\left(\mathrm{F}_{2}\right)$; initiative (0.868), independence $(0.830)$ and activity (0.811) - from the group of managerial qualities $\left(\mathrm{F}_{3}\right)$; resourcefulness $(0.844)$ - from the group of personal self-expression qualities $\left(\mathrm{F}_{4}\right)$. Critical-analytical thinking was among the qualities developed weakest (0.492) out of all the assessed personal qualities.

\section{Discussion}

The majority of authors claim that the efficiency of entrepreneurship education should be evaluated considering the achievement of the goals of the educational programme, the effect of the programmes on their participants, which is evaluated on the basis of the level of achievement of the learning outcomes. Their experience, impact of environment, personal qualities and others can be evaluated (McMullan, Chrisman, \& Vesper, 2001; Strazdiene, 2010; Draycott, Rae, \& Vause, 2011; Athayde, 2012; Paul \& Colwill, 2013).

There is no one opinion about how many and what personal qualities have to be chosen and evaluated, which research methods have to applied for analysis of the collected data to obtain statistically significant results (as all the methods have their limitations) or whether withdrawal of marginal values would introduce changes in research results (components with the highest or lowest factorial weights) and others.

Seeking to acquire as reliable data on the level of development of personal qualities of school learners related to entrepreneurship through SMC activities and to substantiate the efficiency of SMC, the EFA was conducted on the basis of the data of the questionnaire survey of school learners. The obtained data show that the majority of such qualities were developed well and only several of them were developed sufficiently and all this grounds the theoretical propositions about efficiency of SMC developing personal qualities.

Initiative, independence and resourcefulness, i.e., the personal qualities assigned to the most significant ones (Baum \& Locke, 2004; Heinonen \& Poikkijoki, 2006; Covey, 
2006; Petty, 2008; Chell \& Athayde, 2009; Entrepreneurship Education at School in Europe National Strategies, 2012), are developed best in the process of entrepreneurship education.

Initiativeis related to efficient SMC activities, which means assuming responsibility for own activity results (Covey, 2006, p. 82). Initiativeis also perceived as diligence of an individual (Peleckis, Peleckiene, \& Peleckis, 2013, p. 352), which, according to evaluation of school learners, is well developed in SMC activities.

According to G. Petty, independenceboosts school learners' motivation, develops their abilities and attitudes of independent learning, a sense of responsibility and others (Petty, 2008, pp. 417-423). Particularly high level of development of independence can be undoubtedly explained by the fact that all the functions related to SMC activities are conducted by school learners themselves and a teacher is only their facilitator and advisor.

Resourcefulness in SMC activities is related to vivid imagination, creativity, ability to create innovative ideas and to make decisions in the process of activities (Dudaite \& Žibènienè, 2012).

Other personal qualities, such as ambitiousness and activity, were also developed well by school learners involved in SMC activities. Ambitiousness and activity are characteristic of a person, who seeks and possesses a goal. Ambitious individuals feel their personal worth and seek acknowledgement. They are motivated, determined, tough and frequently surpass own expectations, when new challenges are faced (Entrepreneurship Competency Model).

Activity, a personal quality well-developed in SMC activities, is regarded as an intention to act and to take concrete actions (Baum \& Locke, 2004, p. 587, p. 598).

Critical-analytical thinking, which is related to ability to understand and analyse the received information and to make specific decisions (Gudžinskienė, 2006; Jovaiša, 2007). Critical-analytical thinking is a thinking of higher level, which starts with reception and understanding of information and ends up with making of a concrete decision. Critical-analytical thinking serves as basis of reflexive thinking and is related to logical and creative thinking searching for new well-grounded decisions in the process of entrepreneurship. This also embraces ability to perceive and analyse the received information, to envisage problems, to foresee their reasons, ways and consequences of solutions made. In such a case, critical-analytical thinking, a significantly weaker developed personal quality out of all the evaluated ones, can be related to insufficient ability to perceive and analyse the received information and to make concrete decisions.

It is necessary to notice that in scholarly literature sources critical-analytical thinking is linked not to knowledge of business fundamentals but with the business process and business development. Such personal qualities are of higher level and characteristic of heads of enterprises, leaders and used making specific decisions, planning, organising and managing as well as controlling. Since SMC activities are implemented by $5-10$ representatives and the head or director of a mini-company is chosen from the same school 
learners, it is quite possible that they have not reached the level of critical-analytical thinking due to more focus on teachers' instructions.

Good development of the majority of personal qualities can be related to school learners' interest in SMC activities, functions performed there as well as in search for best decisions striving for best possible results. According to the research SMC companies are established the most determined and self-confident school learners. Best developed personal qualities are particularly closely linked with the individual's value-based attitudes because they express the meaning of the supreme goals in the person's life. In various scholarly literature sources entrepreneurship is frequently linked to economic and social welfare. In such case well developed personal qualities of school learners can be applied during the whole economic cycle, result in successful and targeted attainment of set goals implementing a specific assignment or activity, and be linked with future expectations and a positive personal attitude.

\section{Generalisation}

On the basis of the conducted scholarly literature analysis, 18 personal qualities were selected and analysed during the research on development of school learners' personal qualities participating in SMC activities.

The evaluation of personal qualities of school learners involved in SMC activities was conducted employing the multivariate mathematical statistics methods and the efficiency of SMC was substantiated having separately evaluated the structural components of personal qualities divided into the following structural groups: qualities of self-confidence, motivation and activity, leadership qualities, managerial qualities and personal self-expression qualities.

The results of the research showed that participation in activities of SMC has a huge impact on development of personal qualities of school learners. The EFA data (factorial weights) show that the school learners developed their personal qualities well and only several components were developed at sufficient level. Thus, comparison of all the four groups of personal qualities developed by school learners allows to conclude that the qualities of self-confidence, motivation and activity, with the largest dispersion (22.73\%), were developed most.

The highest factorial weights show that diligence (qualities of self-confidence, motivation and activity), ambitiousness (leadership qualities), initiative, independence and activity (managerial qualities) and resourcefulness (personal self-expression qualities) were developed best. Critical-analytical thinking is a quality, which was developed weakest among all the assessed personal qualities. 


\section{References}

Athayde, R. (2012). The impact of enterprise education on attitudes to enterprise in young people: an evaluation study. Education + Training, 54(8/9), 709-726. doi: 10.1108/00400911211274846 Baum, J. R., \& Locke, E. A. (2004). The Relationship of Entrepreneurial Traits, Skill, and Motivation to Subsequent Venture Growth. Journal of Applied Psychology, 89(4), 587-598. doi: 10.1037/0021-9010.89.4.587

Bendrųjų kompetencijų ugdymas. Vidurinio ugdymo bendrųjų programų 10 priedas. (2011). Valstybès žinios, 2011-03-03, Nr. 26-1283.

Beresnevičius, G. (2010). Kūrybiškumo ir kūrybinio mąstymo edukacinès dimensijos. Daktaro disertacija: socialiniai mokslai, edukologija (07S). Šiauliai: Šiaulių universitetas.

Bird, B. (1995). Towards a theory of entrepreneurial competency. In J. A. Katz, R. H. Brockhaus (Eds.), Advances in Entrepreneurship, Firm Emergence and Growth (pp. 51-72). Greenwich, CT: JAI Press.

Bitinas, B. (2011). Edukologijos terminologija: kokybé ir problemos. Klaipèda: Klaipėdos universiteto leidykla.

Building Entrepreneurial Mindsets and Skills in the EU. (2012). Office for Official Publications of the European Union. Luxembourg. doi: 10.2769/40659

Chell, E., \& Athayde, R. (2009). The Identification and Measurement of Innovative Characteristics of Young People: Development of the Youth Innovation Skills Measurement Tool. London: Kingston University. Retrieved from http://eprints.kingston.ac.uk/5985/2/Chell-E-5985.pdf.

Covey, S. R. (2006). 7 sèkmés lydimu žmonių îpročiai. Kaunas: Mijalba.

Čekanavičius, V., \& Murauskas, G. (2000). Statistika ir jos taikymai. I. Vilnius: TEV.

Čekanavičius, V., \& Murauskas, G. (2002). Statistika ir jos taikymai. II. Vilnius: TEV.

Dèl novatoriško verslumo ugdymo sampratos tvirtinimo. (2016). Lietuvos Respublikos švietimo ir mokslo ministro $2016 \mathrm{~m}$. liepos $19 \mathrm{~d}$. ịsakymas Nr. V-655. Retrieved from https://www.e-tar. lt/portal/lt/legalAct/675134304d7b11e6b72ff16034f7f796.

Donielienè, I., Každailytė, V., \& Širiakovienė, A. (2012). Vyresnių klasių mokinių verslumo ugdymo galimybès mokomosiose mokinių bendrovèse. Socialiniai mokslai. Edukologija, 4(37), 20-24. Retrieved from http://vddb.library.lt/fedora/get/LT-eLABa-0001:J.04 2012 ISSN_16488776.N_4_37.PG_20-24/DS.002.0.01.ARTIC.

Draycott, M. C., \& Rae, D. (2011). Enterprise education in schools and the role of competency frameworks. International Journal of Entrepreneurial Behaviour \& Research, 17(2), 127-145. doi: 10.1108/13552551111114905

Draycott, M. C., Rae, D., \& Vause, K. (2011). The Assessment of Enterprise Education in the Secondary Education Sector. Education + Training, 53, 8(9), 673-691. doi: 10.1108/00400911111185017

Dzemyda, G., Kurasova, O., \& Žilinskas, J. (2008). Daugiamačių duomenų vizualizavimo metodai. Vilnius: Mokslo aidai.

Elert, N., Anderssonb, F. W., \& Wennberg, K. (2015). The impact of entrepreneurship education in high school on long-term entrepreneurial performance. Journal of Economic Behavior \& Organization, 111, 209-223. doi: 10.1016/j.jebo.2014.12.020

Entrepreneurship 2020 Action Plan. Reigniting the Entrepreneurial Spirit in Europe. (2013). Brussels, 9.1.2013, COM (2012) 795 final. Retrieved from http://eur-lex.europa.eu/legal-content/LT/ TXT/?uri=CELEX:52012DC0795.

Entrepreneurship Competency Model. Consortium for Entrepreneurship Education. Retrieved from http://www.entre-ed.org/_how/ccr/dol-model.pdf. 
Entrepreneurship Education at School in Europe National Strategies. Curricula and Learning Outcomes. (2012). Education, Audiovisual and Culture Executive Agency. doi:10.2797/80384

Fayolle, A., \& Gailly, B. (2008). From Craft to Science. Journal of European Industrial Training, 32(7), 569-593. doi:10.1108/03090590810899838

Fayolle, A., Gailly, B., \& Lassas, Clerc, N. (2006). Assessing the impact of entrepreneurship education programmes: a new methodology. Journal of European Industrial Training, 30(9), 701-720. doi: 10.1108/03090590610715022

Flash Eurobarometer 354. Entrepreneurship in the EU and Beyond. Report. (2012). DG COMM "Research and Speechwriting" Unit. Retrieved from http://ec.europa.eu/public_opinion/ flash/fl_354_en.pdf.

Garson, G. D. (2013). Factor Analysis. Statistical Associates “Blue Book”. Series Book 15. Kindle Edition. Publisher: Statistical Associates Publishers.

Gudžinskienė, V. (2006). Kritinio mąstymo ịvairios interpretacijos ir jų analizè. Pedagogika. Pedagogy, 81, 107-114. Retrieved from http://www.biblioteka.vpu.lt/pedagogika/PDF/2006/81/ gudz.pdf.

Guidance Supporting Europe's Aspiring Entrepreneurs - Policy and Practice to Harness Future Potential. Research Paper No 14. (2011). Cedefop. Luxembourg: Publications Office of the European Union. doi: 10.2801/86191

Gumuliauskienè, A., \& Vaičiūnienè, A. (2015). Mokytojų lyderystès raiškos ir jos skatinimo ypatumai bendrojo ugdymo mokykloje. Mokytoju ugdymas. Teacher Education, 24(1), 25-47. Retrieved from http://www.su.lt/images/leidiniai/MU/mokytoju_ugdymas_2015_1.pdf.

Halabisky, D. (2012). Entrepreneurial Activities in Europe - Senior Entrepreneurship. OECD Employment Policy Papers, 2. Luxembourg: Publications Office of the European Union. doi: 10.1787/5jxrcml7lhxq-en

Hamilton, S. F., \& Hamilton, M. A. (2012). Development in Youth Enterprises. New Directions for Youth Development, 134, 65-75. doi: 10.1002/yd.20016

Heinonen, J., \& Hytti, U. (2010). Back to Basics: The role of teaching in developing the entrepreneurial university. The International Journal of Entrepreneurship and Innovation, 11(4), 283-292. doi: 10.5367/ijei.2010.0006

Heinonen, J., \& Poikkijoki, S. A. (2006). An Entrepreneurial Directed Approach to Entrepreneurship Education: Mission Impossible? Journal of Management Development, 25(1), 80-94. doi: 10.1108/02621710610637981

Johansen, V., Clausen, T. H., \& Schanke, T. (2013). Entrepreneurship Education and Boys' and Girls' Perceptions of Entrepreneurs. International Journal of Entrepreneurship and Small Business, 19(2), 127-141. doi: 10.1504/IJESB.2013.054960

Johansen, V., \& Schanke, T. (2013). Entrepreneurship Education in Secondary Education and Training. Scandinavian Journal of Educational Research, 57(4), 357-368. doi: 10.1080/00313831.2012.656280

Johansen, V., \& Somby, H. M. (2015). Does the "Pupil Enterprise Programme” Influence Grades Among Pupils with Special Needs? Scandinavian Journal of Educational Research, 1-11. doi: 10.1080/00313831.2015.1085894

Jovaiša, L. (2007). Enciklopedinis edukologijos žodynas. Vilnius: Gimtasis žodis.

Jovaiša, L. (2011). Edukologija. I tomas: Edukologijos j̨vadas. Edukologijos pradmenys. Vilnius: Agora.

Kickul, J., \& Gundry, L. K. (2002). Prospecting for strategic advantage: the proactive entrepreneurial personality and small firm innovation. Journal of Small Business Management, 40(2), 85-97. doi: 10.1111/1540-627X.00042 
Komarkova, I., Conrads, J., \& Collado, A. (2015). Entrepreneurship Competence: An Overview of Existing Concepts, Policies and Initiatives. In-depth case studies report. Luxembourg: Publications Office of the European Union. doi: 10.2791/951054

Komarkova, I., Gagliardi, D., Conrads, J., \& Collado, A. (2015). Entrepreneurship Competence: An Overview of Existing Concepts, Policies and Initiatives. Final Report. Luxembourg: Publications Office of the European Union. doi: 10.2791/067979

Lietuvos Junior Achievement (LJA) [interaktyvus]. Retrieved from http://www.lja.lt

Lietuvos verslumo veiksmų 2014-2020 metu planas. (2014). Lietuvos Respublikos ūkio ministro 2014 m. lapkričio 26 d. ịsakymas Nr. 4-850. TAR, 2014-11-26, Nr. 17989.

Martínez, A. C., Levie, J., Kelley, D. J., Sæmundsson, R. J., \& Schøtt, T. (2010). Global Entrepreneurship Monitor Special Report: A Global Perspective on Entrepreneurship Education and Training. Global Entrepreneurship Research Association (GERA), Universidad del Desarrollo. Retrieved from http://www.babson.edu/Academics/centers/blank-center/globalresearch/gem/Documents/gem-2010-special-report-education-training.pdf.

McMullan, W. E., Chrisman, J. J., \& Vesper, K. H. (2001). Some Problems in Using Subjective Measures of Effectiveness to Evaluate Entrepreneurial Assistance Programs. Entrepreneurship Theory and Practice, 26(1), 37-54. doi: 10.1177/104225870102600103

Mincienè, L. (2000). Verslumo integravimas ị pirminị profesinị rengimą. Pedagogika, 46, 68-75. Mitchelmore, S., \& Rowley, J. (2010). Entrepreneurial competencies: a literature review and development agenda. International Journal of Entrepreneurial Behaviour \& Research, 16(2), 92-111. doi: 10.1108/13552551011026995

Myers, D. G. (2008). Psichologija. Kaunas: Poligrafija ir informatika.

Morkevičius, V. (2008). Statistinès analizès pavyzdžių naudojant pavyzdinę skaitmeninę duomenų bazę medžiaga. Statistine kiekybiniu duomenu analize su SPSS ir STATA. In V. Janilionis, V. Morkevičius, \& R. Rauleckas (Eds.). Kaunas: Kauno technologijos universitetas. Retrieved from http://www.lidata.eu/index.php?file=files/mokymai/stat/stat.html\&course_file=stat_ III_9_1.html.

Mullins, L. J. (2005). Management and Organisational Behaviour (9th ed.). Prentice Hall, Pearson Education, Edinburgh.

Oosterbeek, H., Van Praag, M., \& Ijsselstein, A. (2008). The Impact of Entrepreneurship Education on Entrepreneurship Competencies and Intentions: An Evaluation of the Junior Achievement Student Mini-Company Program. Germany: Bonn, IZA.

Paul, J., \& Colwill, A. (2013). Entrepreneurship Education: an Evaluation of the Young Enterprise Wales initiative. Education + Training, 55 (8/9), 911-925. doi: 10.1108/ET-04-2013-0052

Peleckis, K., Peleckienè, V., \& Peleckis, K. (2013). Verslo vadybos studentų derybinių kompetenciju ugdymas: struktūros ir turinio dimensijos. Verslas: teorija ir praktika. Business: Theory and Practice, 14(4), 346-357. doi: 10.3846/btp.2013.37

Petrulytè, A. (2007). Vidurinès mokyklos sustiprinto mokymosi profilio mokinių kūrybiškumo ypatumai. Pedagogika, 86, 90-97. Retrieved from http://www.biblioteka.vpu.lt/pedagogika/ PDF/2007/86/90-98.pdf.

Petty, G. (2008). Lrodymais pagristas mokymas: praktinis vadovas. Vilnius: Tyto alba.

Pranulis, V. P., \& Dikčius, V. (2012). Rinkodaros tyrimai: teorija ir praktika. Vilnius: Vilniaus universiteto leidykla.

Raosoft. Retrieved from http://www.raosoft.com/samplesize.html.

Ruskovaara, E., \& Pihkala, T. (2015). entrepreneurship education in schools: empirical evidence on the teacher's role. Journal of Educational Research, 108(3), 236-249. doi: 10.1080/00220671.2013.878301 
Sahlberg, P. (2004). Kaip suprantamas mokymasis? In E. Motiejūnienė, E. Pranskūnienè, \& M. Vildžiūnienè (Eds.), Sèkmingo mokymosi link: mokyklų tobulinimo programos A komponento "Mokymo ir mokymosi salygu gerinimas Lietuvos pagrindinése mokyklose" dalinio komponento "Mokytoju kvalifikacijos tobulinimas" I etapo patirtis (2002-2004 m.). Vilnius: Švietimo ir mokslo ministerija.

Strazdienè, G. (2010). Imitacinès verslo įmonès modelio veiksmingumas ugdant kolegiju studentu verslumo gebejimus, 93-100. Retrieved from https://ojs.kauko.lt/index.php/ssktpd/article/ viewFile/81/75 failo html.

Strazdienè, G., \& Garalis, A. (2005). Verslo praktinio mokymo firmų vadovų ir dėstytojų profesinių kompetencijų raiška ir tobulinimo(si) galimybès. Mokytojų ugdymas, 5, 52-58. Retrieved from http://etalpykla.lituanistikadb.lt/fedora/objects/LT-LDB-0001:J.04 2006 1367152540089/ datastreams/DS.002.0.01.ARTIC/content.

Šilingienè, V. (2011). Lyderystès kompetencijos raiška individualios karjeros kontekste. Ekonomika ir vadyba. Economics and Management, 16, 961-968. Retrieved from http://etalpykla. lituanistikadb.lt/fedora/objects/LT-LDB-0001:J.04 2011 1367177864476/datastreams/ DS.002.0.01.ARTIC/content.

Tarptautinių žodžių žodynas. (2013). Vilnius: Alma littera.

Vaitkevičius, R., \& Saudargienè, A. (2006). Statistika su SPSS psichologiniuose tyrimuose. Kaunas: VDU leidykla.

Zabielavičienè, I. (2013). Inovacijos ir kūrybingumas pramonès įmonèje. Verslas: teorija ir praktika. Business: Theory and Practice, 14(3), 240-248. doi: 10.3646/btp.2013.25

\title{
Mokomosios mokinių bendrovès veiksmingumas ugdant asmenines savybes
}

\author{
Džiuljeta Ruškytè
}

Lietuvos edukologijos universitetas, Socialinės edukacijos fakultetas, Ekonomikos ir verslumo ugdymo katedra, T. Ševčenkos g. 31, 03111 Vilnius, dziuljeta.ruskyte@leu.lt

\section{Santrauka}

Remiantis mokslinès literatūros analize, straipsnyje aptariami mokinių mokomųjų bendrovių (MMB) veikloje labiausiai ugdomų asmeninių savybių struktūriniai komponentai.

Mokinių anketinès apklausos statistinių duomenų analizė atlikta ir sudarytų asmeninių savybių parametrai vertinti taikant IBM ${ }^{\circledR}$ SPSS $^{\circledast}$ Statistics for Windows 22.0 (SPSS) specializuotą statistinę programą.

Tiriamoji faktorine analizè (angl. Exploratory Factor Analysis, EFA) taikyta MMB veikloje ugdomų asmeninių savybių struktūrinių komponentų tarpusavio ryšiams nustatyti ir, remiantis tais ryšiais, klasifikuoti juos pagal tam tikrus požymius ị atitinkamus latentinius 
faktorius. Mokinių asmeninių savybių, ugdomų vykdant MMB veiklą, tyrimui, buvo atrinkta ir analizuojama 18 asmeninių savybių.

Taikant EFA atliktas MMB veikloje dalyvavusių mokinių asmeninių savybių vertinimas ir pagrįstas MMB veiksmingumas atskirai įvertinus asmeninių savybių struktūrinius komponentus, suskirstytus $\mathfrak{i}$ atitinkamas struktūrines grupes: Pasitikejimo savimi, motyvacijos ir veiklumo, Lyderio, Vadybines ir Asmens saviraiškos savybes.

Tyrimo rezultatai atskleidè, jog dalyvavimas MMB veikloje daro dideli poveiki mokiniu asmeninių savybių ugdymui(si). Asmeninių savybių ugdymo vykdant MMB veiklą EFA rezultatai parode், kad iš keturių išskirtų asmeninių savybių grupių mokiniai geriausiai išsiugdę Pasitikẻjimo savimi, motyvacijos ir veiklumo savybes.

Didžiausi faktoriniai svoriai rodo, kad iš Pasitikejjimo savimi, motyvacijos ir veiklumo savybiu mokiniai geriausiai išsiugdę veiklumą, iš Lyderio savybių - ambicingumą, iš Vadybinių savybiu gerai išsiugdę iniciatyvumą, savarankiškumą ir aktyvumą, iš Asmens saviraiškos savybiu išradingumą. Silpniausiai iš visų vertintų asmeninių savybių mokiniai yra išsiugdę kritinị ir analitinị mąstymą.

Esminiai žodžiai: asmeninès savybès, mokomoji mokinių bendrové, tiriamoji faktorine analizè, veiksmingumas, verslumo ugdymas. 